\title{
Changes in mean forest age in Canada's forests could limit future increases in area burned but compromise potential harvestable conifer volumes
}

\begin{tabular}{|c|c|}
\hline Journal: & Canadian Journal of Forest Research \\
\hline Manuscript ID & cjfr-2016-0445.R1 \\
\hline Manuscript Type: & Article \\
\hline Date Submitted by the Author: & 27-Jan-2017 \\
\hline Complete List of Authors: & $\begin{array}{l}\text { Boulanger, Yan; Ressources Naturelles Canada, Centre de Foresterie des } \\
\text { Laurentides; Dendrolab, } \\
\text { Girardin, Martin; Natural Resources Canada, Canadian Forest Service } \\
\text { Bernier, Pierre; Natural Resources Canada, Canadian Forest Service, } \\
\text { Laurentian Forestry Centre, } \\
\text { Gauthier, Sylvie; NRC, Canadian Forest Service, } \\
\text { Beaudoin, Andre; Canadian Forest Service, Laurentian Forestry Centre } \\
\text { Guindon, Luc; Canadian Forest Service, Natural Resources Canada }\end{array}$ \\
\hline Keyword: & $\begin{array}{l}\text { fire - vegetation feedbacks, boreal forest, forest fires, climate change, } \\
\text { timber supply }\end{array}$ \\
\hline \multicolumn{2}{|c|}{$\begin{array}{l}\text { Note: The following files were submitted by the author for peer review, but cannot be converted to } \\
\text { PDF. You must view these files (e.g. movies) online. }\end{array}$} \\
\hline \multicolumn{2}{|c|}{$\begin{array}{l}\text { cjfr-2016-0445R1 supp } 1 \text { FractionHarvestableArea_baseline.gif } \\
\text { cjfr-2016-0445R1 supp 2FractionHarvestableArea_RCP26.gif } \\
\text { cjfr-2016-0445R1 supp 3FractionHarvestableArea_RCP45.gif } \\
\text { cjfr-2016-0445R1 supp 4FractionHarvestableArea_RCP85.gif } \\
\text { cjfr-2016-0445R1 supp 5 TotalHarvestedVolume.ha_baseline.gif } \\
\text { cjfr-2016-0445R1 supp 6TotalHarvestedVolume.ha_RCP26.gif } \\
\text { cjfr-2016-0445R1 supp 7 TotalHarvestedVolume.ha_RCP45.gif } \\
\text { cjfr-2016-0445R1 supp } 8 \text { TotalHarvestedVolume.ha_RCP85.gif }\end{array}$} \\
\hline
\end{tabular}

\section{SCHOLARONE $^{m}$ \\ Manuscripts}


1 Title: Changes in mean forest age in Canada's forests could limit future increases in

2 area burned but compromise potential harvestable conifer volumes

5 Authors: Yan Boulanger ${ }^{1 *}$, Martin Girardin ${ }^{1}$, Pierre Y. Bernier ${ }^{1}$, Sylvie Gauthier ${ }^{1}$, André

6 Beaudoin $^{1}$, Luc Guindon $^{1}$

7 * Corresponding author E-mail: yan.boulanger@canada.ca, Tel.: 418-649-6859, Fax:

$8 \quad 418648-5849$

$9{ }^{1}$ Natural Resources Canada, Canadian Forest Service, Laurentian Forestry Centre, 1055

10 du P.E.P.S., P.O. Box 10380, Stn. Sainte-Foy, Québec, QC, Canada G1V 4C7 


\section{Abstract (199 words)}

13 Forest fire activity is projected to increase with climate change in Canada, but vegetation

14 feedbacks are usually not considered. Using new information on the selectivity or

15 avoidance of fire as a function of stand age and composition, we ran simple simulation

16 models that consider the changes in the regional age matrices induced by fire and

17 harvesting to project future burn rates. We also projected estimated future regional

18 vulnerability of timber supply to fire by considering these new burn rates. The inclusion

19 of age-related feedbacks would have a large impact on projected increases in burn rates,

20 mostly in very fire active zone under aggressive climate forcing. Projected burn rates

21 would still increase, but would be 50\% less in 2100 than if projected without this biotic

22 feedback in some zones. Negative feedbacks would be virtually non-existent when

23 potential burning rates are below 1\%, whereas realized burning rates would be lowered

24 by more than 0.5 percentage points when potential burning rates exceed $2.5 \%$. Including

25 fire-vegetation feedbacks had virtually no impact on total volume harvested. As fire burn

26 more old-growth coniferous stands, slightly negative impacts were projected on conifer

27 harvested almost everywhere. These results underline the need to incorporate vegetation

28 - fire feedbacks when projecting future burn rates.

29 Keywords: fire - vegetation feedbacks, boreal forest, forest fires, climate change, timber

30 supply, Canada 


\section{Introduction}

32 Recent shifts observed in burn rates and fire seasonality in boreal North America appear

33 to be directly related to recent changes in climate patterns, mostly in temperature regimes

34 (Gillett et al. 2004; Kasischke and Turestky 2006). Further increases in area burned and

35 the number of fires are projected as a result of warmer temperatures with increased

36 anthropogenic climate forcing (e.g., Balshi et al. 2009a; Wotton et al. 2010; Boulanger et

37 al. 2014; Girardin and Terrier 2015). These modifications of the fire regime could alter

38 future forest ecosystems, notably by shifting species composition (Boulanger et al. 2016),

39 reduce carbon stocks (Kurz et al. 2008; Balshi et al. 2009b), increase fire suppression

40 costs (Podur and Wotton 2010; Hope et al. 2016) and reduce our ability to perform

41 sustainable forest management (Gauthier et al. 2015).

42 Beside climatic ("top-down") controls, it is increasingly acknowledged that burn rates are

43 strongly affected by fuel characteristics as driven by dynamic forest properties such as

44 cover, density, structure and age, known as "bottom-up" controls (Hély et al. 2001, 2010;

45 Krawchuk and Cumming 2011; Héon et al. 2014, Terrier et al. 2013, Girardin et al.

46 2013a). Fire is itself a strong driver of forest properties (Keane et al. 2013), any fire-

47 induced variations in these properties may generate substantial feedbacks on subsequent

48 fire activity (Héon et al. 2014). Fire-prone landscapes could thus be self-regulating and

49 resilient to fire (Héon et al. 2014; Parks et al. 2015). In some Canadian forest regions, it

50 has been suggested that fire generates a negative feedback over a post-fire period of 40-

5150 years (Héon et al. 2014, Erni et al. in press) through the reduction of fuel availability

52 and flammability. As a consequence, one may hypothesize that the temporary expansion

53 of fire-resistant landscapes may attenuate a potential climate change-induced increase in 
54 fire activity. However, because of a general lack of quantitative evidence (Héon et al. 55 2014), fire-vegetation feedbacks are seldom taken into account when projecting future 56 fire activity within the Canadian forests (e.g., Flannigan et al. 2005; Balshi et al. 2009a;

57 Boulanger et al. 2014, but see Krawchuk and Cumming 2011; Terrier et al. 2013;

58 Girardin and Terrier 2015). Such exclusion of biotic feedbacks could have resulted in an 59 overestimation of projected burn rates (Héon et al. 2014).

60 In addition to improving burn rate projections, the inclusion of biotic feedbacks could 61 also provide information as to the future vulnerability of timber supply. Fire competes 62 with harvesting by burning stands that would have been harvested in the future. Negative 63 effects on harvest levels have been estimated to take place only when burn rates are 64 roughly above 0.4\%.yr ${ }^{-1}$ (Boychuk and Martell 1996; Savage et al. 2010; Leduc et al. 65 2015). Recently, using historical harvest levels, Gauthier et al. (2015) identified specific 66 forest management areas across Canada in which projected increases in fire activity 67 might trigger periodic shortfalls in timber supply. However, their study did not take into 68 account biotic feedbacks to fire. Such feedbacks could potentially lower increases in 69 projected burn rate, but also decrease the proportion of mature conifers available for 70 harvest. There is therefore a need to explore whether or not the inclusion of biotic 71 feedbacks affects projected estimates of timber availability.

72 Using medium-resolution maps of fire (Guindon et al. 2014) and spatial estimates of 73 forest properties (Beaudoin et al. 2014), Bernier et al. (2016) recently estimated fire 74 selection ratios for classes of forest composition and age across Canada's managed 75 forests. These quantitative fire selection ratios now offer the possibility to incorporate 76 fire-vegetation feedbacks in order to provide more realistic estimations of future fire 
77 activity. In this study, we project future burn rates across Canada by accounting for

78 dynamic changes in the forest age matrix. Only the effect of age as a biotic feedback is

79 considered in this study as potential changes in forest composition are too uncertain for

80 their inclusion. Forest growth is also assumed to be unchanged. In situations where age

81 feedbacks cannot directly be accounted for in projections (e.g., Bergeron et al. 2004,

82 2006; Flannigan et al. 2005; Balshi et al. 2009a; Girardin et al. 2013a), we propose that it

83 be indirectly accounted for by applying the correction factor presented in caption of Fig.

843 to potential burn rate estimates We further built a model to predict future realized

85 burning rates as a function of potential burning rates (i.e., without fire selectivity) in

86 order to provide a simple solution to correct burn rates in situations where age feedbacks

87 cannot directly be accounted for in projections (e.g., Bergeron et al. 2004, 2006;

88 Flannigan et al. 2005). We hypothesized that the decrease in mean stand age induced by

89 increased burn rates will result in projected burn rates lower than those predicted without

90 the inclusion of such a feedback (e.g., Boulanger et al. 2014). We further hypothesized

91 that the inclusion of biotic feedback to the increased burn rate will result in lower

92 available area and volume for harvest as well as lower coniferous proportions in

93 harvested volumes than when not considering biotic feedback to fire activity.

\section{Material and methods}

95 Our starting point for projection of future burn rates was the Boulanger et al. (2014) study

96 in which future monthly burn rates were projected within Homogeneous Fire Regime

97 (HFR) zones delineated within forested regions of Canada (Figure 1). The projections,

98 which do not take vegetation feedbacks into account, are based on Multivariate Adaptive

99 Spline Regressions (MARS) models using HFR-specific monthly weather metrics. 
100 Models were built using climate and fire data covering the 1959 - 1995 period. Monthly

101 climate variables were computed from daily data obtained from Environment Canada

102 weather stations that were interpolated to the centroid of each HFR zone using BioSIM

103 v10.0.6.20 (Régnière et al. 2014). BioSIM projected daily maximum and minimum

104 temperatures $\left({ }^{\circ} \mathrm{C}\right)$, precipitation $(\mathrm{mm})$, mean daily relative humidity and wind speed by

105 matching georeferenced sources of weather data (weather station with daily weather data)

106 to spatially georeferenced points, adjusting the weather data for differences in latitude,

107 longitude, and elevation between the source of weather data and each cell location by 108 spatial regressions. More details about these fire models can be found in Boulanger et al. 109 (2014). Fire data comes from the Canadian National Fire Data Base. Fire data in models 110 were restricted to large fires, i.e., above 200 ha, as data from smaller fires are known to 111 be incomplete, especially those that occurred before 1980 and in remote areas. These 112 fires were responsible for $97 \%$ of the area burned across Canada during 1959-1997 113 (Stocks et al. 2003). Simulations for the current exercise were done for all HFR zones, 114 except the Eastern Subarctic and the Western subarctic zones on account of poor MARS 115 model fit for burning rates estimations, or the low reliability of initial forest age data, as 116 well as the Pacific zone because of unrealistic behaviour of the conifer yield curves given 117 the area's extreme precipitation values.

\section{Climate data and regional climate-driven burn rates}

119 In Boulanger et al. (2014), future burn rates were projected according to the SRES A2 120 climate scenario used in the previous IPCC fourth assessment report. In this study, we 121 used updated climate projections based on three Representative Concentration Pathways 122 (RCP, e.g., van Vuuren et al. 2011) scenarios, namely RCP 2.6, RCP 4.5 and RCP 8.5. 
123 The RCP 2.6 scenario represents a situation where radiative forcing peaks at $\sim 3 \mathrm{~W} . \mathrm{m}^{-2}$

124 before 2100 and then declines to reach 2.6 W.m ${ }^{-2}$ by 2100 . In the RCP 4.5 scenario,

125 radiative forcing is assumed to stabilize at $4.5 \mathrm{~W} \cdot \mathrm{m}^{-2}$ after 2100 without an "overshoot"

126 pathway. Conversely, in the RCP 8.5 scenario, the forcing reaches $8.5 \mathrm{~W} . \mathrm{m}^{-2}$ in 2100 and

127 continues to increase for some time afterwards. The appropriate outputs from the

128 Canadian Earth System Model version 2 (CanESM2) were downloaded from the World

129 Climate Research Program (WCRP) Climate Model Intercomparison Project Phase 5

130 (CMIP5) archive.

131 Using the stochasticity functionality of BioSIM (Régnière et al. 2014), we simulated

132 three thousand daily time series lasting one year for all combination of HFR zone $\mathrm{x}$

133 climate scenario $\mathrm{x}$ time period. From these daily time series, we then derived the standard

134 components of the Canadian Forest Fire Weather Index System (CFWI) (Van Wagner

135 1987) as well as other temperature- and precipitation-related variables on a monthly-

136 basis. With these variables, regional climate-driven burn rates projections $\left(B R_{\text {regclimt }}\right)$ were

137 computed for all three thousand yearly weather data sets for each HFR zone x climate

138 scenario $\mathrm{x}$ time period using HFR zone-specific MARS models developed by Boulanger

139 et al. (2014).

140 Fire selection ratios

141 Estimates of fire selection ratios for classes of forest age and composition were produced

142 by Bernier et al (2016). Briefly, maps of 2001 forest properties of Canada's managed

143 forests ( Beaudoin et al., 2014) and yearly 2001-2011 Canada-wide maps of fire and

144 harvest (Guindon et al., 2014), both on the 250m MODIS grid, were used to obtain 2001 
145 estimates of age and composition of all pixels with a forest cover $(\geq 80 \%(n=76678906$

146 ) identify pixels, and to identify from this set all pixels that had burned between 2002 and

$1472011(n=2739728)$. All burned and unburned pixels were binned by HFR zone (Table

148 1) in 12 forest cover classes composed of three age classes, i.e., young (0 to 29 years),

149 mature (30 to 89$)$ and old (90+) and for four composition classes i.e., coniferous ( $>75 \%$

150 in conifer species), mixed coniferous (50-75\% in conifer species), mixed hardwood (25-

$15150 \%$ in conifer species $)$ and hardwood $(<25 \%$ in conifer species $)$. Stand properties such

152 as forest composition and age were proved to be powerful and independent classifiers of

153 fire selectivity (Bernier et al. 2016). Indeed, composition (conifers or deciduous species)

154 represents a valuable proxy for flammability, i.e., the propensity to burn, while fuel load,

155 i.e. the amount of flammable biomass, is well-represented by stand age. Lower fire risks

156 have already been associated with young or deciduous stands in regional analyses of fire

157 statistics and forest composition (Héon et al. 2014; Krawchuk and Cumming 2011).

158 Within each HFR zone, the fire selection ratio for a given forest cover class was

159 calculated as the fraction of burned pixels in that cover class divided by fraction of total

160 pixels in that cover class. For a given class, a selectivity ratio of 1 indicated a regional

161 burn rate proportional to its regional availability. A value above 1 indicated fire

162 preference, while a ratio below 1 indicated fire avoidance. These ratios proved to be not

163 affected by large burn rate differences among-HFR and were therefore averaged across

164 HFR zones into Canada-wide mean selection ratios. These mean selection ratios were

165 then attributed to individual pixels using composition and age information, and were

166 combined with the HFR zone's current or projected regional burn rates to estimate the

167 burn probability of each pixel at time $t$. 
169 Regional harvesting levels were retrieved from MODIS-based annual (2001-2011) forest

170 disturbance maps (Guindon et al. 2014) combined with Beaudoin et al. (2014) forest

171 properties maps at a $250 \mathrm{~m}$ resolution. The cumulative aboveground biomass harvested

172 during 2002-2011 was estimated at the 250-m grid cell level and was summarized by

173 "management areas" (i.e., either by forest management units for public lands or by

174 ecodistricts for private lands). These harvesting levels were then directly translated in

175 regional proportions of land harvested at each time step.

176 Calculation of pixel-level volumes

177 Pixel-level yield curves adjusted for conifer species group and for hardwood species 178 group, developed by Gauthier et al. (2015) for the same forest cover dataset than in our 179 study, were used to estimate changes in total volume and in volume harvested in each 180 HFR zone. These curves were formulated as:

181 (eq. 1)

$$
\log (V)=\beta_{0}+\beta_{1}+\beta_{2}+\frac{\beta_{3}+\beta_{4} T+\beta_{5} P}{A}
$$

182 where $V$ is the pixel-level volume (in $\mathrm{m}^{3} \cdot \mathrm{ha}^{-1}$ ) based on all tree's woody and foliar 183 components, $A$ is stand age, $T$ is historical (1970-2000) mean annual air temperature of 184 the pixel $\left({ }^{\circ} \mathrm{C}\right), P$ is historical mean annual precipitation of the pixel $(\mathrm{mm})$, and $\beta_{0}$ to $\beta_{5}$ 185 are adjusted parameters (see Ung et al. 2009). The conversion from logarithmic units to 186 arithmetic units entailed the use of a correction factor, as suggested by Duan (1983) (in 187 Ung et al. 2009):

$$
V=\exp [\log (V)] * C_{D}
$$


189 where $C_{D}$, the Duan correction factor, is equal to the mean of exponentiated residuals. For 190 each pixel, we merged the results of the two curves according to the proportion of 191 coniferous and hardwood species at time $t=0$ based on the Beaudoin et al. (2014) forest 192 composition maps. The resulting composite yield curve was then rescaled according to a 193 ratio of measured to modeled $V$ at age at time $t=0$ to force the curves to locally adjust 194 the observations (Gauthier et al. 2015). We did not attempt to model changes in growth 195 rate as a result of predicted changes in precipitation or temperature using eq. 1 as its the 196 formulation was designed to be only descriptive of the current interaction between 197 climate and species distribution (Ung et al, 2009).

\section{Simulations}

199 For each HFR zone and climate scenario combinations, we ran non spatially-explicit 200 simulations including both fire and harvesting as stand replacing disturbances. Two sets 201 of simulation were conducted, i.e., one including the impact of fire selectivity relative to 202 stand age and composition classes and another where fire selectivity was not considered. 203 For each set, sixty simulations were run for 100 years using a 5-yr time step, starting in 204 2000. Initial pixel-level age, volume and coniferous/hardwood fraction were derived from 205 the 2001 forest cover maps of Beaudoin et al. (2014). Pixels in which the forest was 206 identified as recently disturbed prior to 2001 (Guindon et al. 2014) or comprising $<80 \%$ 207 of vegetation cover (Beaudoin et al. 2014) at time $t=0$ were not considered in 208 simulations.

209 Stochasticity at each simulation time step stemmed from the random selection i) of pixels 210 to be burned, ii) of pixels to be harvested, and iii) of the regional climate-driven burn 
211 probability $\left(B R_{\text {regclimt }}\right)$. At each time step, a value of $B R_{\text {regclimt }}$ was randomly drawn from

212 the 3000 values available for that time period under the given climate scenario for that

213 HFR zone. As in Bernier et al. (2016), burn probabilities (eq. 3) were normalized within

214 each HFR zone by dividing by the mean probability of the twelve forest cover classes

215 (Table 1) at time $t=0$ (BaselineMeanP), thereby transforming the probabilities into a set

216 of normalised selection ratios (Manly 1993).

217 The burning of a given pixel at time $t$ was then drawn from a binomial distribution with 218 probabilities Prob $_{\text {burn }}$ estimated from:

(eq. 3) $\quad$ Prob $_{\text {burn }}=B R_{\text {regclimt }} *$ cover $_{m} *$ linear $_{\text {mod }} * t_{\text {step }} /$ BaselineMeanP

221 where $t_{\text {step }}$ is time step length in years (i.e., 5), cover $_{m}$ (Table 1) is the fire selectivity ratio

222 of the forest cover class of this pixel, and linear ${ }_{\text {mod }}$ is a correction factor included to

223 consider a linear trend in $B R_{\text {regclimt }}$ within each 30 -yr periods. The cover $_{m}$ was set to 1 for

224 all forest cover classes in simulation where fire selectivity was not considered. Burn rate

225 was then assessed as the annual proportion of burned pixels at each time step. The

226 potential burning rate $\left(B R_{p o t}\right)$ was defined as the burning rate simulated when no fire

227 selectivity was included in simulations whereas the realized burning rate $\left(B R_{\text {rea }}\right)$

228 corresponded to the burning rate calculated in simulations with fire selectivity.

229 Harvesting was applied at the management area level after burning in the simulations. For

230 a given time period and management area, the harvesting rate was area-based and was

231 initialized at the mean yearly 2001-2011 level observed in the Guindon et al (2014)

232 dataset in each management area. Only pixels that reached commercial maturity, here 
233 arbitrarily defined as $V=100 \mathrm{~m}^{3} \cdot \mathrm{ha}^{-1}$, could be randomly selected for harvesting (as in

234 Gauthier et al. 2015, see also Raulier et al. 2013). At each time step, the harvest rate was

235 allowed to adjust downward with the decreasing availability of harvestable stands as a

236 result of both fire and harvest. Indeed, simulated harvest rates were capped to the number

237 of harvestable pixels when this number was lower than the historical harvest rates. A

238 random number of pixels were then selected for harvesting according to the adjusted

239 regional harvesting levels. Coniferous and hardwood volumes within harvested pixels

240 were considered to have been entirely removed in their respective proportion. The age of

241 pixels that were selected for burning or harvesting was then reset to 0 , but their

242 composition remained unchanged from the 2001 estimates provided by Beaudoin et al

243 (2014). By doing so, we thus assume (as in Bernier et al. 2016) that burn rates in

244 harvested and post-fire stands are similar. Other pixels were aged accordingly to time

245 step length, while their new volume was estimated following equations 1 and 2.

246 The burning rate was computed for each HFR zone at each time step for each simulation.

247 In order to assess if we could develop a correction factor for burned rates that were

248 estimated without considering the vegetation selectivity, we modeled realized burning

249 rates as a function of potential burning rates as averaged over the 100 -yr period using the

250 following nonlinear least square model:

$251 \quad($ eq. 4$)$

$$
B R_{\text {rea }}=v^{*} B R_{\text {pot }} /\left(k+B R_{p o t}\right)
$$

252 where $v$ (maximum achievable $B R_{\text {rea }}$ ) and $k$ (potential burning rate at which rate of

253 increase in $B R_{\text {rea }}$ is half of $v$ ) are the two constants to parameterize. The sixty burning

254 rates coming from the same simulation dataset of a given HFR zone were averaged in 
255 order to avoid pseudoreplication, leaving four observations per HFR zone (one for each 256 forcing scenario, total $\mathrm{N}=52$ ). In parallel, we also estimated the following variables at 257 the management area level in all simulations: i) the realized harvesting rates, expressed as 258 the yearly proportion of vegetated area harvested and ii) the total, conifer and hardwood 259 volume harvested. Simulations were performed using R 3.2.4 (R Core Team 2016). The 260 nonlinear regression model was fitted using the $n l s$ function in R.

\section{Results}

\section{Impacts on burn rates}

263 Effects of age-related biotic feedback on projected increases in burn rate was important in 264 the great majority of HFR zones, but was more pronounced in zones with higher 265 projected fire activity under the most important climate forcing RCP 8.5, i.e. Great Slave 266 Lake, Lake Athabasca, Lake Winnipeg, Eastern James Bay, Western Ontario and 267 Southwestern Yukon. Therein the inclusion of age-related biotic feedback generated large 268 drops in projected burn rates increases as compared to projections that did not incorporate 269 such feedbacks (Fig. 2). These feedbacks lowered projected burn rates increases by as 270 much as half the potential burn rate, representing a difference of 2 to 8 percentage points

271 in annual area burned, under the RCP 8.5 climate scenario. Furthermore, high fire activity 272 as simulated under baseline condition was sufficient in Eastern James Bay and Lake 273 Athabasca zones to generate negative feedback and to decrease annual area burned by 0.5 $274-1$ percentage points. Rather strong negative feedbacks (25-30\%) were also simulated 275 for The Great Bear Lake and Interior Cordillera zones under RCP 8.5 by 2100 . Important 276 but lower negative feedbacks were also generated for all these zones under RCP 2.6 and 
277 RCP 4.5 (Fig. 2). Negative feedbacks were minimal regardless of climate forcing in

278 Eastern Temperate, North Atlantic, and Western James Bay zones. As a rule of thumb,

279 potential and realized annual burning rates when averaged over a 100 year period were

280 generally similar below 1\% (Fig. 3). Burning rates clearly diverged at higher values:

281 realized annual burning rates was lowered by more than 0.5 percentage point when the

282 potential burning rate exceeded $2.5 \%$, and by more than 2 percentage points when the

283 potential burning rate exceeded 5.5\% (Fig. 3).

284 Even with these negative feedbacks, burn rates were projected to increase in virtually all

285 HFR zones as a result of increase anthropogenic climate forcing when compared to actual

286 (2000) burning rates (Fig. 2). Increases remained substantially higher under the most

287 aggressive (RCP 8.5) climate forcing scenario. Burn rates were projected to remain the

288 highest in HFR zones located in central Canada (Lake Athabasca and Lake Winnipeg

289 HFR zones), reaching ca $6-7 \%$ by 2100 under RCP 8.5. Divergences in burn rates

290 among the three climate forcing scenarios were perceptible mostly after ca 2050 in the

291 majority of HFR zones.

292 Impacts on harvesting

293 Accounting for biotic feedbacks on projected future burn rates had virtually no impact on

294 harvested area and total volume harvested (Figures 4 and 5). Exceptions were for Eastern

295 James Bay where volume harvested would be ca $60 \%$ higher by 2100 under RCP 8.5

296 when considering biotic feedbacks. However, the inclusion of biotic feedback in

297 projections of burn rates slightly reduced the proportion of conifer potentially harvested

298 in Eastern James Bay, Interior Cordillera and Western Ontario as compared to 
299 simulations that did not include such feedbacks (Figure 6). The proportion of potential 300 harvested conifer volume was lower by $5 \%$ to $10 \%$ under RCP 8.5 as well as, to a lesser 301 degree, under milder forcing scenarios. Virtually no impacts were simulated elsewhere 302 (Figure 6).

303 Compared to current (2000) levels, higher burn rates very slightly decreased potential 304 harvestable areas to levels lower than those necessary to maintain historical harvesting 305 rates (in terms of area harvested), but only in Eastern James Bay only under RCP 8.5 306 beyond 2075 (Fig. 4). Negative impacts when compared to current volume harvested 307 remained minimal elsewhere with the exception of Interior Cordillera for which 308 harvestable volume would drop by $20-30 \%$ by 2100 depending of climate forcing. The 309 potential harvestable volume was projected to increase regardless of forcing scenario and 310 most markedly in Eastern Temperate and Southern Cordillera (Figure 5). However, 311 decreases in the proportion of potential harvestable conifer volume were projected 312 especially for most fire active zones under the most aggressive climate forcing. Decreases 313 were important in Eastern James Bay, Western Ontario and Interior Cordillera (10 - 20\% 314 under RCP 8.5 by 2100). 


\section{Discussion}

316 This study provides nationwide projections of future burn rates that account for climate

317 change effects on fire risks and dynamic feedbacks between fire and mean landscape age.

318 Our approach based on Canada-wide maps of disturbances and vegetation features

319 contrasts with approaches taken by typical process-based models in which biotic

320 feedbacks to burn rates are modelled using complex and interacting climate, fuel and

321 ignitions submodels (e.g., Arora and Boer 2005, Scheller et al. 2007, Keane et al. 2011).

322 Given their intrinsic complexity, these models have to sacrifice either spatial extent (e.g.,

323 forest landscape models) or resolution (e.g. Terrestrial Ecosystem Models), thereby

324 compromising their ability to obtain Canada-wide assessments of biotic feedbacks to

325 future fire activity and their inherent impact on timber supply. The issue of sustainable

326 forest management within a climate change context urgently needs to be addressed, and

327 advances as proposed here based on the characterisation of disturbances and vegetation

328 features by remote-sensing may offer valuable insights.

329 Future burn rates could be substantially constrained by biotic feedbacks, especially in 330 zones where burn rates were projected to be high (Boulanger et al. 2014, Balshi et al.

331 2009a). Indeed, a steady decrease in mean forest age could temper future increases in 332 burn rates by more than $50 \%$ in some HFR zones in 2100 , notably in Lake Winnipeg, 333 Lake Athabasca, Eastern James Bay and Great Slave Lake. Comparable attenuations 334 under warmer and drier climates were projected for the occurrence of large fires when 335 considering negative vegetation feedback resulting from boreal needleleaf transition to 336 boreal mixedwood landscapes (Girardin et al. 2013a). Likewise, Héon et al. (2014) 337 showed that increasing the proportion of young stands significantly reduced the potential 
338 burn rates of a highly fire-prone region within the boreal forest. Nevertheless, biotic 339 feedbacks would not be sufficient to completely offset the climate-induced increase in 340 fire activity relative to baseline conditions in most HFR zones as projected burn rates are 341 likely to attain or exceed the range of natural variability in burn rates observed within the 342 last millennia (Bergeron et al. 2004, Girardin et al. 2013b). In other zones and under mild 343 climate forcing, negative feedbacks were rather small to non-existent: original projections 344 of burning rates were low and current forest landscape cover proportions were not 345 sufficient to significantly lower burn rates. Indeed, we found that negative biotic 346 feedbacks would be virtually non-existent when potential burning rates are below $1 \%$. 347 Burn rates that were previously projected to values below $1 \%$ without consideration of 348 biotic feedbacks should not be corrected for negative feedback. Most regional projections 349 of future burn rates for most of Canada correspond to these conditions (e.g., Flannigan et 350 al. 2005; Bergeron et al. 2006; Balshi et al. 2009; Boulanger et al. 2014; Suppl. Mat S1). 351 However, realized burning rates would be lowered by more than 0.5 percentage points 352 when potential burning rates exceed $2.5 \%$ over a $100-y r$ period. There is hence clearly a 353 need for accounting for such feedbacks when projecting future burning rates. In situations 354 where age feedbacks cannot directly be accounted for in projections (e.g., Bergeron et al. 355 2004, 2006; Flannigan et al. 2005; Balshi et al. 2009a; Girardin et al. 2013a), we propose 356 that it be indirectly accounted for by applying the correction factor presented in caption 357 of Fig. 3 to potential burn rate estimates. By doing so, it can be shown that studies 358 projecting large increases in area burned under climate change be biased by the non359 accounting for age feedbacks (Suppl. Mat. S1). 
360 We found that the inclusion of age-related feedbacks could lower the proportion of 361 conifer potentially harvested while, contrary to our expectations, having no impact on 362 total harvested volume. The same applies for harvestable stands as for mean stand age 363 (Suppl. Mat. S2). Such apparently contradictory results stem from our premise of no 364 harvesting preference between coniferous and hardwood stands. The selection ratios of 365 Bernier et al. (2016) give conifers a higher-than-average risk of burning and hardwoods a 366 lower-than-average one. As time progresses, in the most fire-prone HFR zones, the 367 proportion of conifer stands that reach commercial maturity (above $100 \mathrm{~m}^{3} \cdot \mathrm{ha}^{-1}$ ) thus 368 tends to decrease while that of deciduous stands tends to increase, giving as a result a 369 either rather stable or slightly decreasing (when burn rates are high) area in mature 370 coniferous stands available for harvest. Harvesting substitution of coniferous for 371 hardwood stands is highly theoretical at this point and would imply a change in forest 372 management paradigms for which the short-term achievability remains to be explored. 373 Currently, softwood comprises the great majority of volume harvested in Canada's forest 374 regions (Natural Resources Canada 2015), and management strategies (including 375 plantations) are largely implemented to favor softwood species over hardwood species. 376 Consequently, current harvesting strategies directly "compete" with fire as they both tend 377 to "select" mature coniferous stands. Including harvesting preferences in simulations 378 could thus reveal a much worst portrait in future potential harvestable volume.

379 Our results concur with those of Gauthier et al. 2015a in which forest regions in interior 380 British Columbia, northwestern Ontario and north central Quebec (see Suppl. Mat. S3) 381 may be at higher risk of timber shortfall especially within management areas where tree 382 growth is slow, timber harvest is important and projected increases in burn rate are 
383 significant. When compared to the situation prevailing in 2000, several FMUs located in 384 these zones would experience a decrease in the proportion of harvestable stands (i.e. 385 stands with merchantable volume greater than $100 \mathrm{~m}^{3} \mathrm{ha}^{-1}$ ) and hence total volume 386 harvested. Our analyses also suggest that, even with the current baseline fire and 387 harvesting conditions, timber availability in some of these FMUs may decrease within the 388 next decades (Suppl. Mat. S3), with potential impacts on the supply value chain even 389 without considering increased climate forcing (Irland et al. 2001; Williamson et al. 2009; 390 Gauthier et al. 2015a). Prior work has suggested that salvage logging can mitigate but 391 never eliminate fire impacts on timber availability (Leduc et al, 2015).

392 There are numerous limitations to our analyses. Simplistic assumptions about fire 393 selectivity that do not incorporate complex fire initiation and fire spread functions as 394 computed by process-based models (e.g., Burn-P3, FIREBGCv2, Parisien et al. 2005; 395 Keane et al. 2011) were used in our model. As such, fine-scale topographic and weather 396 conditions are not taken into account in burned area projections. As mentioned above, the 397 extent at which our analyses were performed impedes the use of these complex process398 based fire models. Also, we have not incorporated the extent to which successional 399 changes in forest composition e.g., from conifers to hardwood species, could act as an 400 additional feedback mechanism in response to increased fire activity. The reason for this 401 exclusion is simply uncertainties regarding post-fire succession rules as affected by 402 climate change at the scale of Canada. Possible conversion of late-succession coniferous 403 stands to mixed- or hardwood stands could further strengthen negative feedbacks 404 considering higher foliar moisture loading and lower flammability for broadleaf species 405 (Päätalo 1998; Hély et al. 2001) and could further decrease harvested conifer volume. 
406 Furthermore, anticipated northward migration of hardwood mesophytic species at the 407 expense of boreal coniferous species, notably along the boreal-temperate transition zone 408 (Boulanger et al. 2016, McKenney et al. 2011) could also further hinder fire activity 409 (Carcaillet et al. 2010; Girardin et al. 2013a; Terrier et al. 2013). Other partial or stand410 replacing disturbances (e.g., windthrow, insect outbreaks) that would have further 411 lowered mean age were not considered. Also, we used Bernier et al. (2016) fire 412 selectivity ratios for which similar values are attributed to young stands of all ages 413 between 0 and 29 years. Recent studies (Erni et al. 2016, Héon et al. 2014) found that 414 negative age-related biotic feedbacks exponentially decrease during this successional 415 stage. Consequently, feedbacks might be much more important than simulated in zones 416 where projections suggested the potential for very short fire return intervals (e.g., $<20$ 417 years). Furthermore, fire selectivity ratios computed by Bernier et al. (2016) did not 418 consider different potential flammability between e.g., post-fire and harvested stands. 419 Both of these stand types are likely to evolved different fuel load and type, notably fine 420 fuel abundance, making recently harvested stands being more prone to fire initiation than 421 post-fire stands (Krawchuk and Cumming 2009). One might then expect higher burn 422 rates than simulated in areas where harvest is a significant component (e.g., Eastern 423 James Bay and Interior Cordillera). In addition, our projections imply stable fire 424 suppression efficiency in the future. However, more frequent period of high fire load 425 might significantly decrease the efficiency of fire protection agencies if management 426 resources are kept unchanged (Podur and Wotton 2010), thus leading to higher overall 427 burn rates. Continuous monitoring will be needed to document potential changes in biotic 428 feedbacks. 
429 By integrating biotic feedbacks on fire activity, our analyses likely reduced the 430 uncertainties related to the projection of future burn rates, and could therefore improve 431 projections of nationwide e.g., carbon budget (Bond-Lamberty et al. 2007), smoke 432 (Anderson 2013), delivered wood costs (McKenney et al. in prep), biodiversity (Stralberg 433 et al. 2015) and community vulnerability to fire (Beverly and Bothwell 2011). Our 434 analyses suggested that some forest regions might be at higher risk of timber shortfall 435 especially within management areas where tree growth is slow and projected increases in 436 burn rate are significant (Gauthier et al. 2015). As projected climate-induced decrease in 437 forest productivity were not included in this study, some regions might face a double438 whammy, i.e., a decrease of harvestable volume through higher fire activity and 439 decreased climate-induced productivity along with potential changes in softwood 440 proportions available for harvest. Serious impacts on the supply value chain are thus to be 441 expected (Irland et al. 2001; Williamson et al. 2009; Gauthier et al. 2015) with potential 442 effects on market prices of forest products and consumer preferences (McCarl et al. 2000; 443 Hanewinkel et al. 2012). Given the extent to which fire selectivity and biotic feedbacks to 444 fire might impact wood type and wood volume available, we therefore advocate for their 445 thorough consideration when projecting future timber resources. In this context, rapid 446 adaptation of the forest sector is paramount (Lemprière et al. 2008; Williamson et al. 447 2009; Ochuodho et al. 2012; Edwards and Hirsch 2012). 
449

450

451

452

453

454

455

456

457

458

459

460

461

462

463

464

465

466

467

468

\section{Literature cited (54)}

Anderson, K. 2013. Canadian Safety and Security Program Project Charter. 2013 Smoke forecasts from wildland fires for Canada. CSSP-2013-CP-1019.Version 1.7a. 11 $\mathrm{pp}$

Arora, V.K., Boer, G.J. (2005) Fire as an interactive component of dynamic vegetation models. J. Geogr. Res. 110:G02008.

Balshi, M.S., McGuire, A.D., Duffy, P., Flannigan, M., Walsh, J., Melillo, J. 2009a. Assessing the response of area burned to changing climate in western boreal North America using a Multivariate Adaptive Regression Splines (MARS) approach. Glob. Change Biol. 15: 578-600. doi:10.1111/j.13652486.2008.01679.x.

Balshi, M.S., McGuire, A.D., Duffy, P., Flannigan, M., Kicklighter, D.W., Melillo, J. 2009b. Vulnerability of carbon storage in North American boreal forests to wildfires during the $21^{\text {st }}$ century. Glob. Change Biol. 15:1491-1510.

Beverly, J.L., Bothwell, P. 2011. Wildfire evacuations in Canada 1980-2007. Nat. Hazards 59: 571-596.

Beaudoin, A., Bernier, P.Y., Guindon, L., Villemaire, P., Guo, X.J., Stinson, G., Bergeron, T., Magnussen, S., Hall, R.J. 2014. Mapping attributes of Canada's forests at moderate resolution through $k \mathrm{NN}$ and MODIS imagery. Can. J. For. Res. 44:521-532. 
469

470

471

472

473

474

475

476

477

478

479

Bergeron, Y., Flannigan, M., Gauthier, S., Leduc, A., Lefort, P. 2004. Past, current and future fire frequency in the Canadian boreal forest: Implications for sustainable forest management. Ambio 33:356-360.

Bergeron, Y., Cyr, D., Drever, C.R., Flannigan, M., Gauthier, S., Kneeshaw, D., Lauzon, E., Leduc, A., Le Goff, H., Lesieur, D., Logan, K. 2006. Past, current, and future fire frequencies in Quebec's commercial forests: implications for the cumulative effects of harvesting and fire on age-class structure and natural disturbance-based management. Can. J. For. Res. 36: 2737-2744.

Bernier, P.Y., Gauthier, S., Jean, P.O., Manka, F., Boulanger, Y., Beaudoin, A., Guindon, L. 2016. Mapping local effects of forest properties on fire risk across Canada. Forests 7: 157.

Bond-Lamberty, B., Peckham, S.D., Ahl, D.E., Gower, S.T. 2007 Fire as the dominant driver of central Canadian boreal forest carbon balance. Nature 450:89-92.

Boulanger, Y., Gauthier, S., Burton, P.J. 2014. A refinement of models projecting future Canadian fire regimes using homogeneous fire regime zones. Can. J. For. Res. 44:365-376.

Boulanger, Y., Taylor, A.R., Price, D.T., Cyr, D., McGarrigle, E. , Rammer, W., SteMarie, G., Beaudoin, A., Guindon, L., Mansuy, N. 2016. Climate change impacts on forest landscapes along the Canadian southern boreal forest transition zone. Landsc. Ecol. (in press)

Boychuk, D.B., Martell, D.L. 1996. A multistage stochastic programming model for sustainable forest-level timber supply under risk of fire. For. Sci. 42: 10-26. 
491 Carcaillet, C., Richard, P.J.H., Bergeron, Y., Fréchette, B., Ali, A.A. 2010. Resilience of 492 the boreal forest in response to Holocene fire-frequency changes assessed by pollen diversity and population dynamics. Int. J. Wild. Fire 19:1026-1039.

Duan, N. 1983. Smearing estimate: a nonparametric retransformation method. J. Am. Stat. Assoc. 78: 605-610. doi:10.1080/01621459.1983.10478017.

Edwards, J.E., Hirsch, K.G. 2012. Adapting sustainable forest management to climate change: preparing for the future. Can. Counc. For. Minist., Ottawa, ON.

Erni. S., Arseneault, D., Parisien, M.-A., Bégin, Y. 2016. Spatial and temporal dimensions of fire activity in the fire-prone eastern Canadian taiga. Glob. Change Biol. In press

Flannigan, M.D., Logan, K.A., Amiro, B.D., Skinner, W.R., Stocks, B.J. 2005. Future area burned in Canada. Clim. Change 72: 1-16. doi:10.1007/s10584-005-5935-y.

Gauthier, S., Bernier, P.Y., Boulanger, Y., Guo, J., Guindon, L., Beaudoin, A., Boucher, D. 2015. Vulnerability of timber supply to projected changes in fire regime in Canada's managed forests. Can. J. For. Res. 45:1439-1447.

Gillett, N.P., Weaver, A.J., Zwiers, F.W., Flannigan, M.D. 2004. Detecting the effect of climate change on Canadian forest fires. Geophysical Research Letters 31:L18211.

Girardin, M.P., Ali, A.A., Carcaillet, C., Blarquez, O., Hély, C., Terrer, A., Genries, A., Bergeron, Y. (2013a) Vegetation limits the impact of a warm climate on boreal wildfires. New. Phytol. 199:1001-1011. 
512 Girardin, M.P., Ali, A.A., Carcaillet, C., Gauthier, S., Hély, C., Le Goff, H., Terrier, A., 513 Bergeron, Y. 2013b. Fire in managed forests of eastern Canada: Risks and options. For. Ecol. Manage. 294:238-249.

Girardin, M.P., Terrier, A. 2015. Mitigating risks of future wildfires by management of the forest composition: an analysis of the offsetting potential through boreal Canada. Clim. Change 130: 587-601 .

Guindon, L., Bernier, P.Y., Beaudoin, A., Pouliot, D., Villemaire, P., Hall, R.J., Latifovic, R., St-Amant, R. 2014. Annual mapping of large forest disturbances across Canada's forests using 250 m MODIS imagery from 2000 to 2011. Can. J. For. Res. 44:1545-1554.

Hanewinkel, M., Cullman, D.A., Schelhaas, M.J., Nabuurs, G.J., Zimmermann, N.E. 2012. Climate change may cause severe loss in the economic value of European forest land. Nature Clim. Change 3:203-207.

Hély, C., Flannigan, M., Bergeron, Y., McRae, D. 2001. Role of vegetation and weather on fire behaviour in the Canadian mixedwood boreal forest using two fire behaviour prediction systems. Can. J. For. Res. 31:430-441.

Hély, C., Fortin, M.-J., Anderson, K.R., Bergeron, Y. 2010. Landscape composition influences local pattern of fire size in the eastern Canadian boreal forest: role of weather and landscape mosaic on fire size distribution in mixedwood boreal forest using the Prescribed Fire Analysis System. Int. J. Wild. Fire 19: 1099-1109.

Héon, J., Arseneault, D., Parisien, M.-A. 2014. Resistance of the boreal forest to high burn rates. Proc. Nat. Acad. Sci. 111:13888-13893. 
534 Hope, E.S., McKenney, D.W., Pedlar, J.H., Stocks, B.J., Gauthier, S. 2016. Wildfire 535 Suppression Costs for Canada under a Changing Climate. PLoS ONE. 11(8):e0157425.

\section{7}

538
Irland, L.C., Adams, D., Alig, R., Betz, C.J., Chen, C.C., Hutchins, M., McCarl, B.A., Skog, K., Sohngen, B.L. 2001. Assessing socioeconomic impacts of climate change on US forests, wood-product markets, and forest recreation. BioScience 51:753-764.

Kasischke, E.S., Turetsky, M.R. 2006. Recent changes in the fire regime across the North American boreal region - spatial and temporal patterns of burning across Canada and Alaska. Geophys. Res. Lett. 33: L09703. doi:10.1029/2006GL025677

Keane, R.E., Loehman, R.A., Holsinger, L.M. 2011. The FireBGCv2 Landscape Fire Succession Model: A research simulation platform for exploring fire and vegetation dynamics. USDA. Forest Service, Rocky Mountain Research Station General Technical Report RMRS-GTR-255.

Keane, R.W., Cary, G.J., Flannigan, M.D., Parsons, R.A., Davies, I.D., King, K.J., Li, C., Bradstock, R.A., Gill, M. 2013. Exploring the role of fire, succession, climate, and weather on landscape dynamics using a comparative modeling. Ecol. Model. 266:172-186.

Krawchuk, M.A., Cumming, S.G. 2009. Disturbance history affects lightning fire initiation in the mixedwood boreal forest: Observations and simulations. For. Ecol. Manage. 257:1613-1622. 
555 Krawchuk, M.A., Cumming, S.G. 2011. Effects of biotic feedback and harvest

556

557

558

559 management on boreal forest fire activity under climate change. Ecol. Appl. 21:122-136.

Leduc, A., Bernier, P.Y., Mansuy, N., Raulier, F., Gauthier, S., Bergeron, Y. 2015. Using salvage logging and tolerance to risk to reduce the impact of forest fires on timber supply calculations. Can. J. For. Res. 45:480-486.

Lemprière, T.C., Bernier, P.Y., Carroll, A.L., Flannigan, M.D., Gilsenan, R.P., McKenney, D.W., Hogg, E.H., Pedlar, J.H., Blain, D. 2008. The importance of forest sector adaptation to climate change. Natural Resources Canada, Canadian Forest Service, Northern Forestry Centre, Edmonton, Alberta. Information Report NOR-X-416E. 78 p.

Manly, B., McDonald, L., Thomas, D. 1993. Resource Selection by Animals: Statistical Design and Analysis for Field Studies; Chapman and Hall, New York, NY, USA, $221 \mathrm{pp}$.

McCarl, B.A., Adams, D.M., Alig, R.J., Burton, D., Chen, C.C. 2000 Effects of global climate change on the US forest sector: response functions derived from a dynamic resource and market simulator. Clim. Res. 15:195-205.

McKenney, D.W., Pedlar, J.H., Rood, R.B., Price, D.T. 2011. Revisiting projected shifts in the climate envelopes of North American trees using updated general circulation models. Glob. Change Biol. 17:2720-2730.

Natural Resources Canada (2015) State of Canada's Forests. 76 pp. 
576 Ochuodho, T.O., Lantz, V.A., Lloyd-Smith, P., Benitez, P. 2012. Regional economic 577 impacts of climate change and adaptation in Canadian forests: A CGE modeling analysis. For. Pol. Econom. 25:100-112.

579 Päätalo, M.L. 1998. Factors influencing occurrence and impacts of fires in northern 580 European forests. Silv. Fenn. 32:185-202.

Parks, S.A., Holsinger, L.M., Miller, C., Nelson, C.R. 2015. Wildland fire as a selfregulating mechanism: the role of previous burns and weather in limiting fire progression. Ecol. Appl. 25:1478-1492.

Parisien, M.A., Kafka, V.G., Hirsch, K.G., Todd, J.B., Lavoie, S.G., Maczek, P.D. 2005. Mapping wildfire susceptibility with the BURN-P3 simulation model. Nat. Resour. Can., Can. For. Serv., North. For. Cent., Edmonton, Alberta. Inf. Rep.

Podur, J., Wotton, M. 2010. Will climate change overwhelm fire management capacity? NOR-X-405. 36 p. [ http://cfs.nrcan.gc.ca/publications?id=25627 ]

Ecol. Model. 221: 1301-1309. doi:10.1016/j.ecolmodel.2010.01.013.

R Core Team 2016. R: A language and environment for statistical computing. $\mathrm{R}$ Foundation for Statistical Computing, Vienna, Austria. URL https://www.Rproject.org/.

Raulier, F., Ouzennou, H., Saucier, J.-P., Bergeron, Y., Campagna, M., and Lord, D. 2013. Productivité : description du cirtère de l'indicateur, justification des seuils, méthodes retenues et résultats détaillés. In Rapport du comité scientifique chargé d'examiner la limite nordique des forêts attribuables. Ministère des Ressources naturelles du Québec (MRN), Secteur des forêts. Appendix 6, pp. 25-77. 
598

599

600

601

602

603

604

605

606

607

608

609

610

611

612

613

614

615

616

617

618

Régnière, J., St-Amant, R., Béchard, A. 2014. BioSIM 10 User's manual. Natural Resources Canada, Canadian Forest Service, Information Repost LAU-X-137E. URL: http://cfs.nrcan.gc.ca/pubwarehouse/pdfs/34818.pdf (last accessed 14/06/2016).

Savage, D.W., Martell, D.L., Wotton, M.B. 2010. Evaluation of two risk mitigation strategies for dealing with fire-related uncertainty in timber supply modelling. Can. J. For. Res. 40:1136-1154.

Scheller, R.M., Domingo, J.B., Sturtevant, B.R., Williams, J.S., Rudy, A., Gustafson, E.J., Mladenoff, D.J. 2007. Design, development, and application of LANDIS-II, a spatial landscape simulation model with flexible spatial and temporal resolution. Ecol. Model. 201:409-419.

Stralberg, D., Bayne, E.M., Cumming, S.G., Solymos, P., Song, S.J., Schmiegelow, K.A. 2015. Conservation of future boreal forest bird communities considering lags in vegetation response to climate change: a modified refugia approach. Div. Distrib. 21:1112-1128.

Terrier, A., Girardin, M.P., Périé, C., Legendre, P., Bergeron, Y. 2013. Potential changes in forest composition could reduce impacts of climate change on boreal wildfires. Ecol. Appl. 23:21-35.

Ung, C.H., Bernier, P.Y., Guo, X., Lambert, M.C. 2009 A simple growth and yield model for assessing changes in standing volume across Canada's forests. For. Chron. 85:57-64. doi:10.5558/tfc85057-1. 
619 van Vuuren, D.P., Edmonds, J., Kainuma, M., Riahi, K., Thomson, A., Hibbard, K., 620 Hurtt, G.C., Kram, T., Krey, V., Lamarque, J.F., Masui, T., Meinhausen, M., 621 Nakicenovic, N., Smith, S.J., Rose, S.K. 2011. The representative concentration 622 pathways: An overview. Clim. Change 109:5-31.

623 Van Wagner, C.E. 1987. Development and structure of the Canadian Forest Fire Weather 624 Index System. Forestry Technical Report 35. Canadian Forestry Service, Ottawa, 625 Canada.

626 Williamson, T.B., Colombo, S.J., Duinker, P.N., Gray, P.A., Hennessey, R.J., Houle, D., 627 Johnston, M.H., Ogden, A.E., Spittlehouse, D.L. 2009. Climate change and 628 Canada's forests: from impacts to adaptation. Natural Resources Canada, 629 Canadian Forest Service, Northern Forestry Centre, Edmonton, Alberta, 630 Sustainable Forest Management Network, University of Alberta, Edmonton, $631 \quad$ Alberta. 112 p.

632 Wotton, B.M., Nock, C., Flannigan, M.D. 2010. Forest fire occurrence and climate 633 change in Canada. Int. J. Wild. Fire 19:253-271. doi:10.1071/WF09002. 
635 Table 1. Fire selectivity ratios (cover $m$ in eq. 3) as a function of forest age and

636 composition classes used in simulations considering biotic feedback to fire activity. A

637 ratio of 1 indicated that regional burn rates for a given each class was proportional to its

638 regional availability while values above 1 indicated fire selection while ratio below 1

639 indicated fire avoidance.

\begin{tabular}{|c|c|c|c|}
\hline $\begin{array}{l}\text { Composition classes } \\
\text { (\% of conifer) }\end{array}$ & $\begin{array}{c}\text { Young } \\
(\mathbf{0}-\mathbf{3 0} \text { yrs })\end{array}$ & $\begin{array}{c}\text { Age classes } \\
\text { Mature } \\
(30-90 \text { yrs }) \\
\end{array}$ & $\begin{array}{c}\text { Old } \\
(>90 \text { yrs })\end{array}$ \\
\hline $\begin{array}{l}\text { Conifer } \\
(>75 \%)\end{array}$ & 0.80 & 2.00 & 2.90 \\
\hline $\begin{array}{l}\text { Mixed-Conifer } \\
(50-75 \%)\end{array}$ & 0.43 & 1.16 & 1.79 \\
\hline $\begin{array}{l}\text { Mixed-Hardwood } \\
(25-50 \%)\end{array}$ & 0.22 & 0.57 & 0.96 \\
\hline $\begin{array}{l}\text { Hardwood } \\
(<25 \%)\end{array}$ & 0.15 & 0.40 & 0.63 \\
\hline
\end{tabular}

640 


\section{$641 \quad$ Figure captions}

642 Figure 1. Homogeneous fire regime (HFR) zones as delineated in Boulanger et al. (2014) 643 along with their associated burn rates $\left(\% \cdot \mathrm{yr}^{-1}\right)$ for the $1959-1999$ period. EJB: Eastern 644 James Bay; ET: Eastern Temperate; GBL: Great Bear Lake; GSL: Great Slave Lake; IC: 645 Interior Cordillera; LA: Lake Athabasca; LW: Lake Winnipeg; NAT: North Atlantic; SC: 646 Southern Cordillera; SP: Southern Prairies; SY: Southwestern Yukon; WJB: Western 647 James Bay; WO: Western Ontario. Eastern Subarctic (ES), Pacific (P) and Western 648 Subarctic (WS) HFR zones were not included in the analyses.

649 Figure 2. Mean burn rates $\left(\% \cdot \mathrm{yr}^{-1}\right)$ according to different anthropogenic forcing scenarios 650 when considering (solid lines) or not (dashed lines) fire - vegetation feedbacks within 651 each HFR zone. Black: Baseline climate; Blue: RCP 2.6; Yellow: RCP 4.5; Red: RCP 652 8.5. Note that the scale of $y$ axis is variable.

653 Figure 3. a) Realized burning rates as a function of potential burning rates. Recall that 654 these rates were averaged over the 100-year period. See figure 2 for color meaning. The 655 1:1 line is shown dashed. The full black line illustrates the nonlinear fitted model where $656 B R_{\text {rea }}=9.466 * B R_{\text {pot }} /\left(9.254+B R_{\text {pot }}\right) . \mathrm{N}=52$; Pseudo-Rsquare $\left.=0.992 . \mathrm{b}\right)$ Importance 657 of the negative feedback ( $\%$ of burning rate) as a function of potential burning rates. This 658 basically represents the 1:1 line minus the full black line in figure $3 a$.

659 Figure 4. Proportion of the HFR zone total area harvested (\%) per year according to 660 different anthropogenic forcing scenarios when considering (solid lines) or not (dashed 661 lines) fire - vegetation feedbacks. See figure 2 for color meaning. 
662 Figure 5. Same as figure 4 but for total harvested volume $\left(\mathrm{m}^{3} \cdot \mathrm{ha}^{-1} \cdot \mathrm{yr}^{-1}\right)$. Only HFR zones 663 where initial yearly proportion of harvested area was above $0.05 \%$ are shown.

664 Figure 6. Proportion of conifer volume harvested (\%) according to different

665 anthropogenic forcing scenarios when considering (solid lines) or not (dashed lines) fire 666 vegetation feedbacks. See figure 2 for color meaning. Only HFR zones where initial 667 yearly proportion of harvested area was above $0.05 \%$ are shown.

668

669 


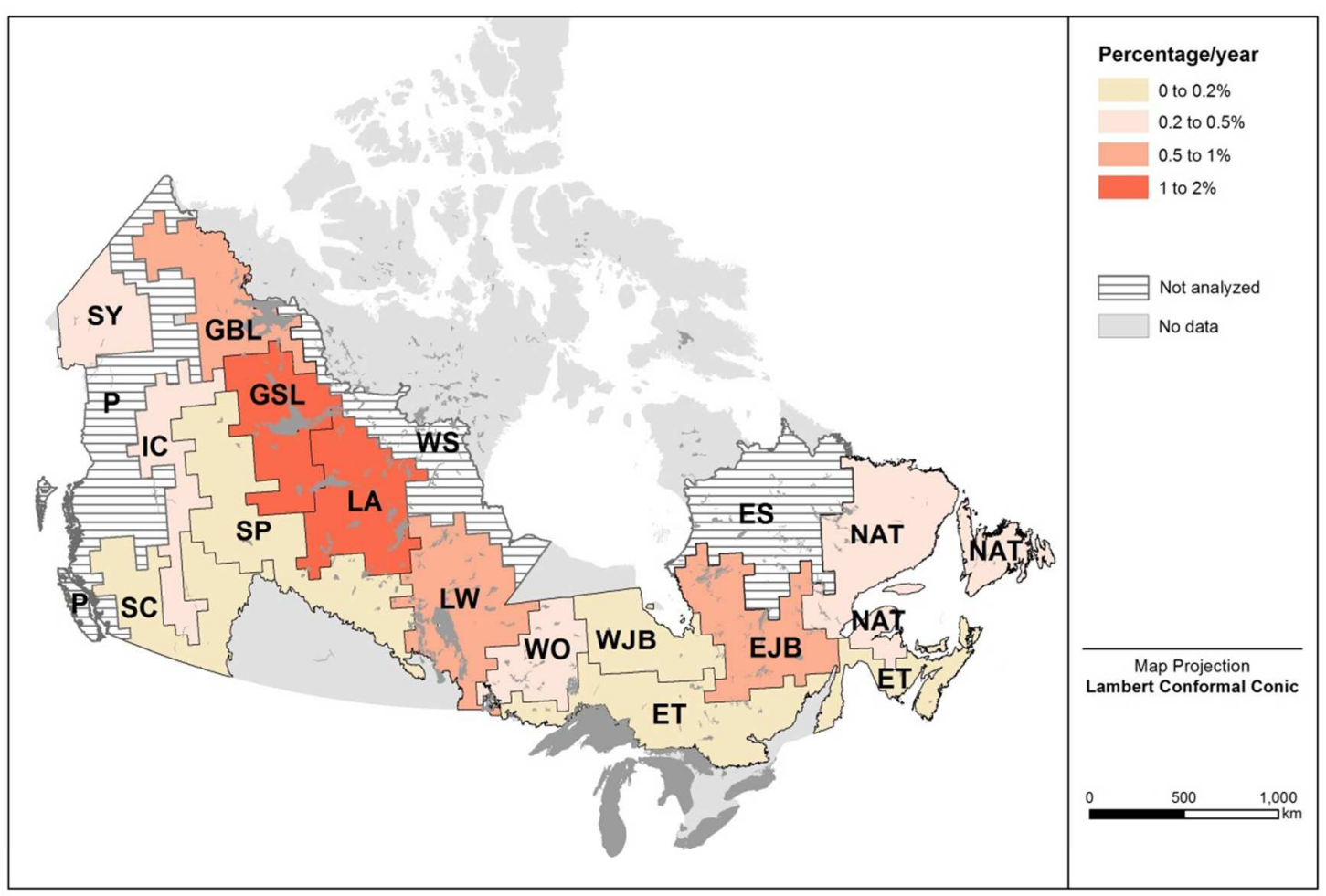

671

672 Figure 1

673 


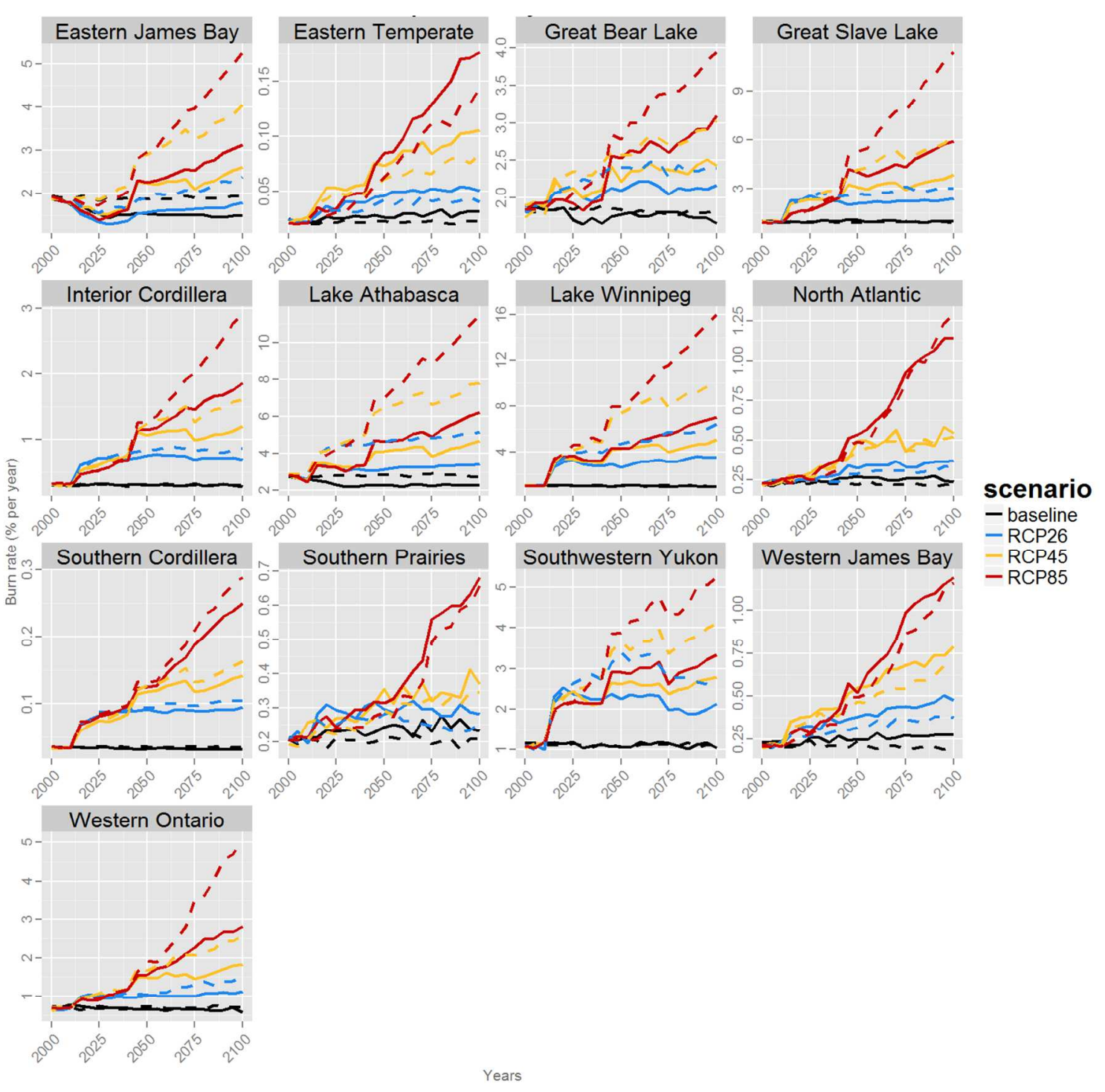

675

676

677 Figure 2

678

679 


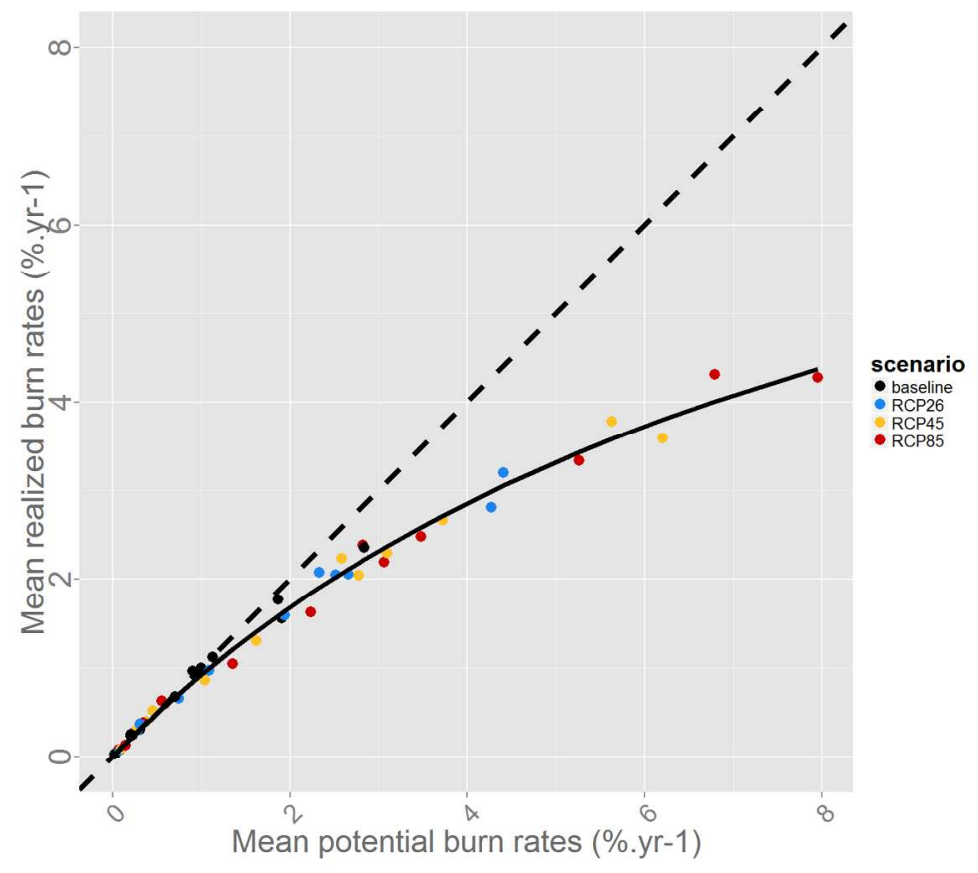

681

682

b)

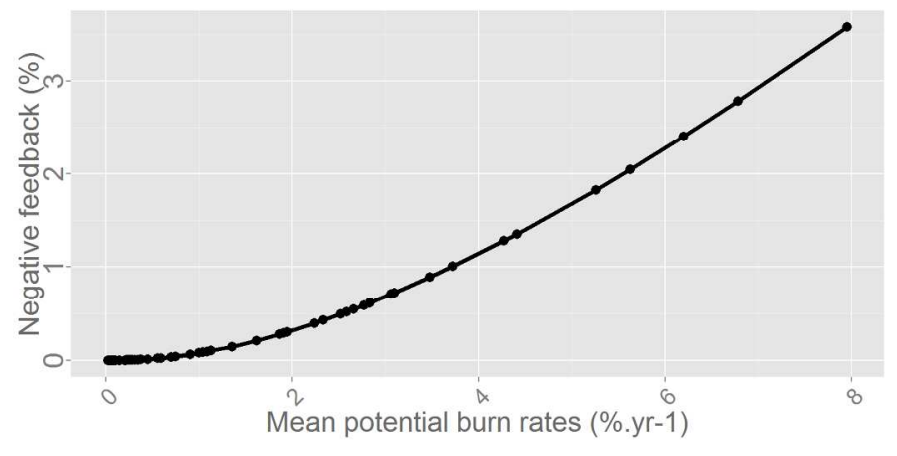

684 Figure 3

685 


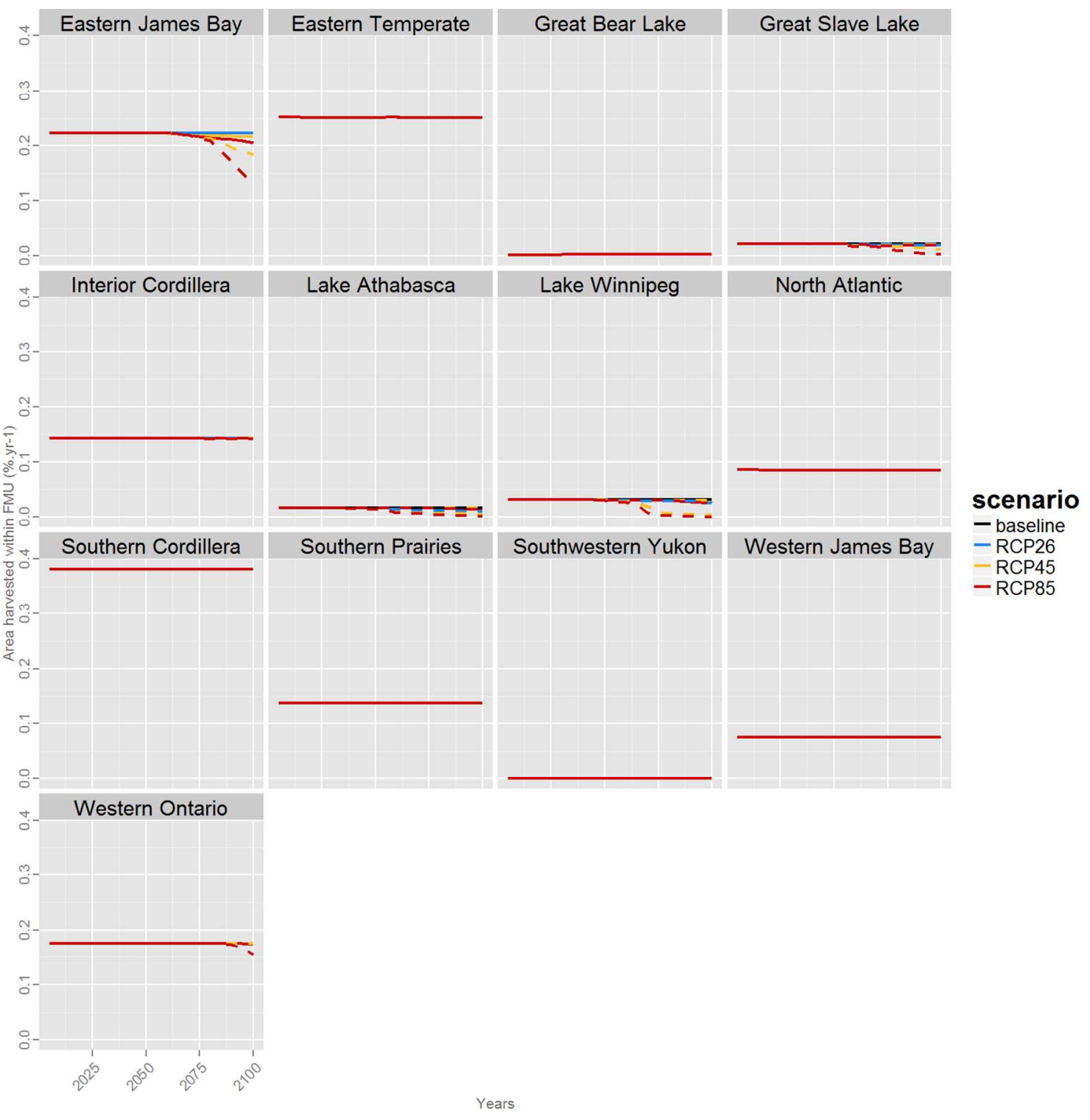

687 Figure 4 


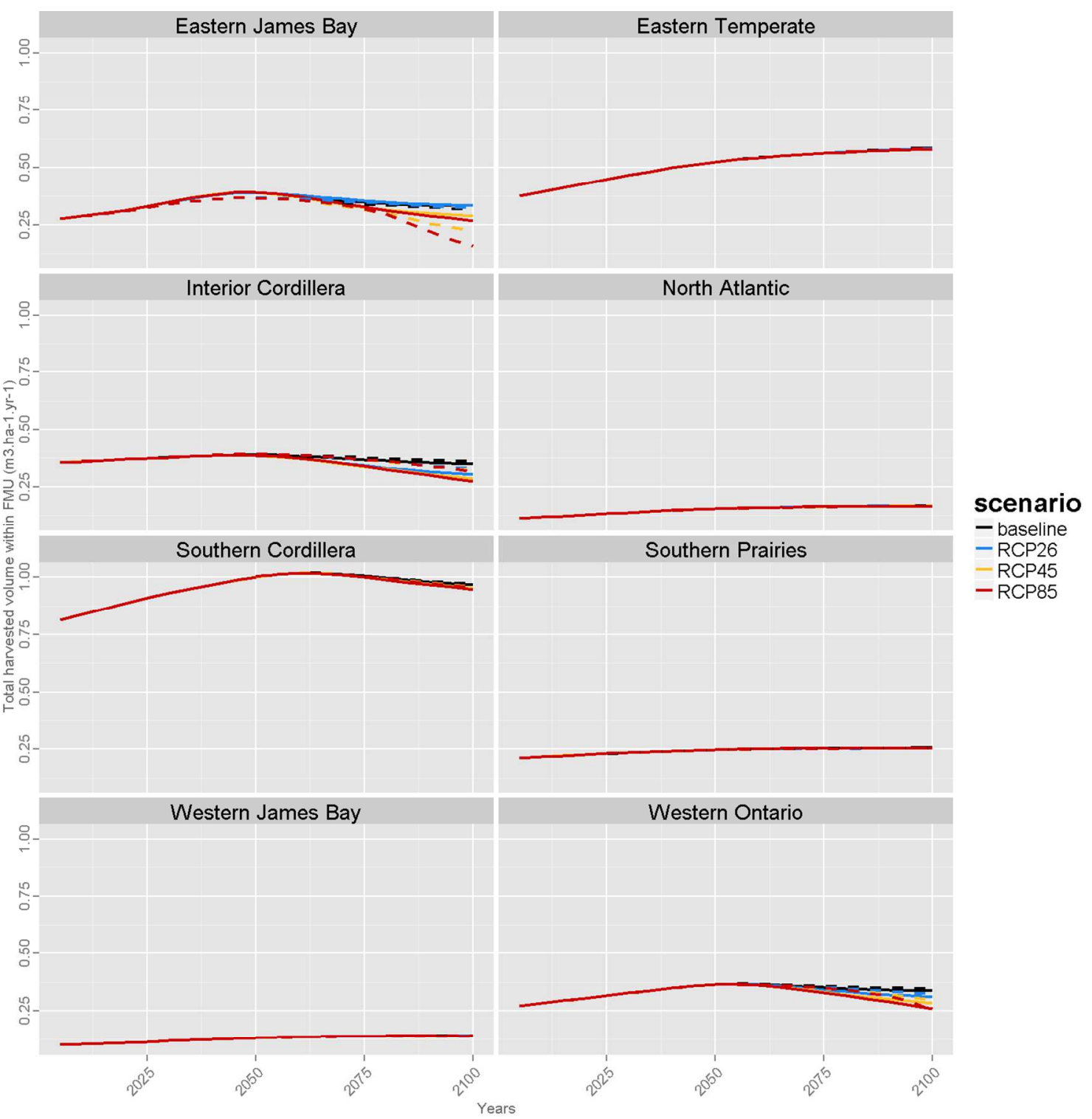

691

692 Figure 5

693 

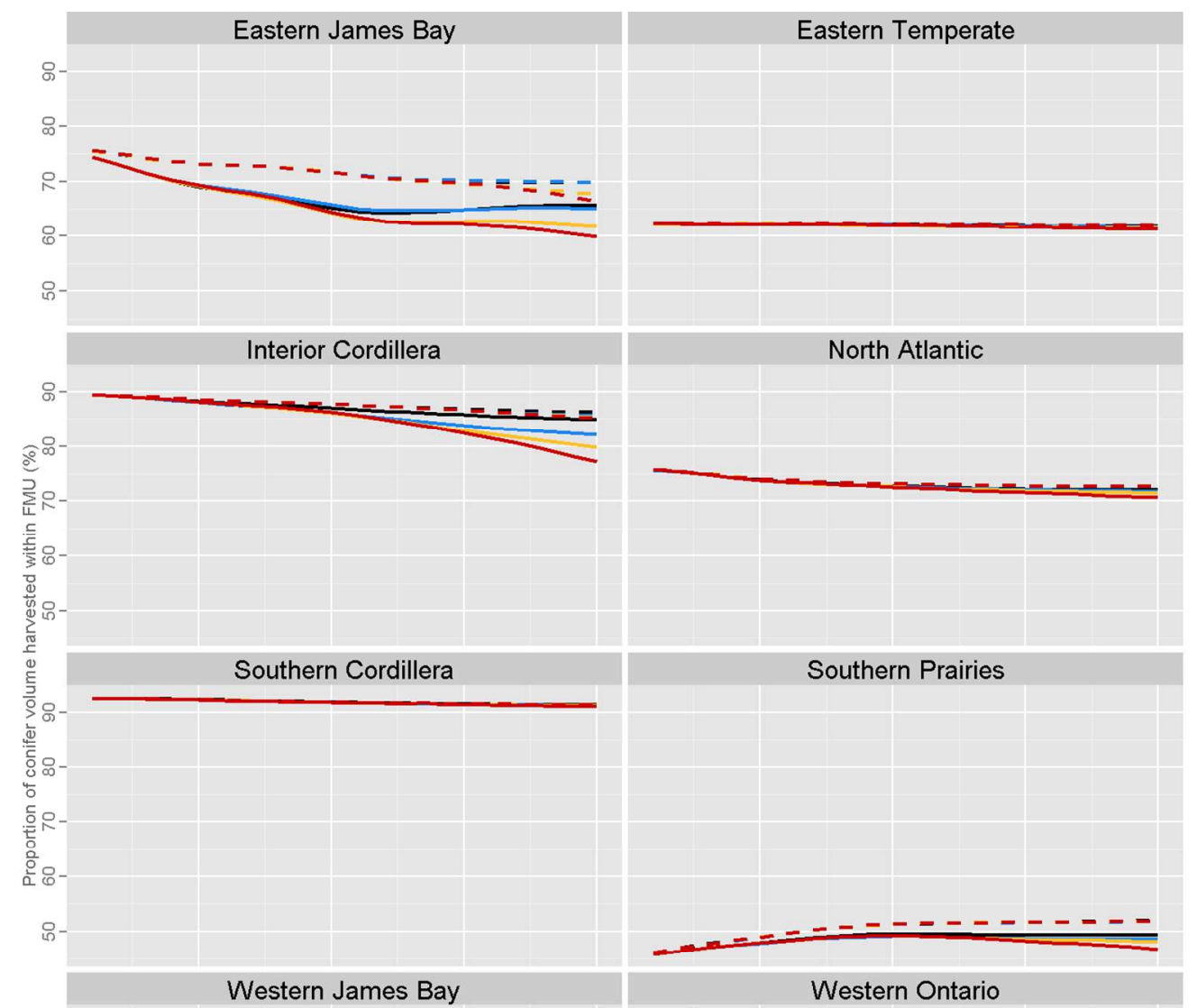

scenario

- baseline

- RCP26

- RCP45

- RCP85

695 Figure 6 
697 Supplementary material S1 - Proposed corrections (in red) for negative feedbacks of future burning rates previously projected by

698 Bergeron et al. (2004, 2006) and Flannigan et al. (2005). Previously published burning rates above 1\% per year are in bold.

a) Bergeron et al. (2004)

\begin{tabular}{|c|c|c|c|c|c|c|c|c|c|c|}
\hline $\begin{array}{l}\text { Site } \\
\text { No }\end{array}$ & Study area & $\begin{array}{c}\text { Current } \\
\text { burn } \\
\text { rate } \\
(\%)\end{array}$ & $\begin{array}{c}2 \times \mathrm{CO} 2 \\
\text { burn } \\
\text { rate }\end{array}$ & $\begin{array}{c}3 x \mathrm{CO} 2 \\
\text { burn } \\
\text { rate }\end{array}$ & $\begin{array}{c}\text { 2xCO2 } \\
\text { burn } \\
\text { rate } \\
\text { Adjusted }\end{array}$ & $\begin{array}{c}3 \mathrm{xCO} 2 \\
\text { burn } \\
\text { rate } \\
\text { Adjusted }\end{array}$ & $\begin{array}{c}2 \times \mathrm{CO} 2 \\
/ \\
\text { current } \\
\text { ratio }\end{array}$ & $\begin{array}{c}3 \times \mathrm{CO2} \\
/ \\
\text { current } \\
\text { ratio }\end{array}$ & $\begin{array}{c}2 \times \mathrm{CO} 2 \\
\text { / current } \\
\text { ratio } \\
\text { Adjusted }\end{array}$ & $\begin{array}{c}3 \times \mathrm{CO} 2 \\
\text { / current } \\
\text { ratio } \\
\text { Adjusted }\end{array}$ \\
\hline 1 & $\begin{array}{l}\text { Jasper Park } \\
\text { W. Central }\end{array}$ & 0.027 & 0.000 & 0.000 & 0.000 & 0.000 & 0.000 & 0.000 & 0.000 & 0.000 \\
\hline 2 & Alberta & 0.019 & 0.024 & 0.028 & 0.025 & 0.028 & 1.253 & 1.418 & 1.278 & 1.446 \\
\hline 3 & Glacier Park & 0.063 & 0.000 & 0.000 & 0.000 & 0.000 & 0.000 & 0.000 & 0.000 & 0.000 \\
\hline 4 & Yoho Park & 0.049 & 0.000 & 0.000 & 0.000 & 0.000 & 0.000 & 0.000 & 0.000 & 0.000 \\
\hline 5 & Kootenay & 0.065 & 0.000 & 0.000 & 0.000 & 0.000 & 0.000 & 0.000 & 0.000 & 0.000 \\
\hline 6 & $\begin{array}{l}\text { Kananaskis } \\
\text { Wood Buffalo }\end{array}$ & 0.050 & 0.000 & 0.000 & 0.000 & 0.000 & 0.000 & 0.000 & 0.000 & 0.000 \\
\hline 7 & $\begin{array}{l}\text { Park } \\
\text { Northern }\end{array}$ & 0.660 & 0.812 & 0.773 & 0.764 & 0.729 & 1.230 & 1.170 & 1.157 & 1.105 \\
\hline 8 & Alberta & 0.222 & 0.351 & 0.427 & 0.346 & 0.417 & 1.580 & 1.920 & 1.557 & 1.877 \\
\hline 9 & Rutledge Park & 0.903 & 1.210 & 1.734 & 1.095 & 1.494 & 1.340 & 1.920 & 1.212 & 1.654 \\
\hline 10 & $\begin{array}{l}\text { Prince Albert } \\
\text { Northern }\end{array}$ & 0.470 & 0.451 & 0.484 & 0.440 & 0.470 & 0.960 & 1.030 & 0.936 & 1.001 \\
\hline 11 & Ontario & 0.462 & 1.998 & 2.658 & 1.681 & 2.112 & 4.330 & 5.760 & 3.643 & 4.577 \\
\hline 12 & LAMF & 0.046 & 0.060 & 0.064 & 0.061 & 0.065 & 1.320 & 1.410 & 1.342 & 1.432 \\
\hline 13 & Western & 0.032 & 0.033 & 0.048 & 0.033 & 0.049 & 1.019 & 1.500 & 1.038 & 1.526 \\
\hline
\end{tabular}




\begin{tabular}{|c|c|c|c|c|c|c|c|c|c|c|}
\hline & Quebec & & & & & & & & & \\
\hline 14 & $\begin{array}{l}\text { Algonquin } \\
\text { Park } \\
\text { Abitibi east }\end{array}$ & 0.007 & 0.007 & 0.006 & 0.007 & 0.006 & 0.985 & 0.836 & 1.007 & 0.854 \\
\hline 15 & $\begin{array}{l}\text { Quebec } \\
\text { Northern }\end{array}$ & 0.032 & 0.026 & 0.020 & 0.027 & 0.021 & 0.811 & 0.632 & 0.827 & 0.645 \\
\hline 16 & boreal Quebec & 0.261 & 0.415 & 0.869 & 0.406 & 0.812 & 1.590 & 3.330 & 1.557 & 3.114 \\
\hline 17 & $\begin{array}{l}\text { Central Quebec } \\
\text { Southeastern }\end{array}$ & 0.111 & 0.000 & 0.000 & 0.000 & 0.000 & 0.000 & 0.000 & 0.000 & 0.000 \\
\hline 18 & Labrador & 0.038 & 0.057 & 0.068 & 0.057 & 0.069 & 1.491 & 1.799 & 1.516 & 1.827 \\
\hline
\end{tabular}

701 


\begin{tabular}{|c|c|c|c|c|c|c|}
\hline Site No. & Study Area & $\begin{array}{c}\text { Current } \\
\text { burn rate } \\
(\%)\end{array}$ & $\begin{array}{c}2 \times \mathrm{CO} 2 \\
\text { burn rate } \\
(\%)\end{array}$ & $\begin{array}{c}3 \times \mathrm{CO2} \\
\text { burn } \\
\text { rate }(\%)\end{array}$ & $\begin{array}{c}2 \times \mathrm{CO} 2 \\
\text { burn rate } \\
(\%) \\
\text { Adjusted }\end{array}$ & $\begin{array}{c}3 \times \mathrm{CO} 2 \\
\text { burn rate } \\
(\%) \\
\text { Adjusted }\end{array}$ \\
\hline 1 & Abitibi northwest & 0.239 & 0.394 & 1.262 & 0.387 & 1.136 \\
\hline 2 & Abitibi southwest & 0.258 & 0.282 & 0.302 & 0.280 & 0.299 \\
\hline 3 & Abitibi east & 0.239 & 0.394 & 1.262 & 0.387 & 1.136 \\
\hline 4 & Abitibi southeast & 0.048 & 0.064 & 0.072 & 0.065 & 0.073 \\
\hline 5 & $\begin{array}{l}\text { Temiscamingue } \\
\text { north } \\
\text { Temiscamingue }\end{array}$ & 0.048 & 0.064 & 0.072 & 0.065 & 0.073 \\
\hline 6 & south & 0.036 & 0.03 & 0.02 & 0.031 & 0.020 \\
\hline 7 & Waswanipi & 0.239 & 0.394 & 1.262 & 0.387 & 1.136 \\
\hline 8 & Central Quebec & 0.258 & 0.282 & 0.302 & 0.280 & 0.299 \\
\hline 9 & North Shore & 0.155 & 0.179 & 0.384 & 0.180 & 0.377 \\
\hline 10 & Gaspesia & 0.205 & 0.306 & 0.503 & 0.303 & 0.488 \\
\hline
\end{tabular}




\begin{tabular}{|c|c|c|c|c|c|c|c|}
\hline $\begin{array}{l}\text { Modified ecozones } \\
\text { (No.) }\end{array}$ & Area with fuel (ha)* & $\begin{array}{c}\text { AAB** } \\
3 \text { x CO2 } \\
\text { Canadian§ } \\
\text { (ha) }\end{array}$ & $\begin{array}{c}\text { AAB } \\
3 \times \text { CO2 } \\
\text { Hadley } \S \\
\text { (ha) }\end{array}$ & $\begin{array}{c}\text { AAB } \\
3 \times \text { CO2 } \\
\text { Canadian } \\
(\%)\end{array}$ & $\begin{array}{c}\text { AAB } \\
3 \times \text { CO2 } \\
\text { Hadley } \\
(\%)\end{array}$ & $\begin{array}{c}\mathrm{AAB} \\
3 \times \mathrm{CO} 2 \\
\text { Canadian } \\
(\%) \\
\text { Adjusted }\end{array}$ & $\begin{array}{c}\text { AAB } \\
3 \times \text { CO2 } \\
\text { Hadley } \\
(\%) \\
\text { Adjusted }\end{array}$ \\
\hline Boreal Cordillera (12) & 33924875 & 36000 & 353000 & 0.11 & 1.04 & 0.11 & 0.96 \\
\hline Boreal Plains (9) & 63233813 & 237000 & 751000 & 0.37 & 1.19 & 0.37 & 1.08 \\
\hline $\begin{array}{l}\text { Eastern Boreal Shield } \\
(62)\end{array}$ & 90664044 & 252000 & 266000 & 0.28 & 0.29 & 0.28 & 0.29 \\
\hline $\begin{array}{l}\text { Taiga Shield + } \\
\text { Hudson Plains (5) }\end{array}$ & 116821963 & 821000 & 817000 & 0.70 & 0.70 & 0.67 & 0.67 \\
\hline $\begin{array}{l}\text { Montane Cordillera } \\
\text { (14) }\end{array}$ & 38385800 & 0 & 51000 & 0.00 & 0.13 & 0.00 & 0.13 \\
\hline Taiga Cordillera (11) & 16804213 & 88000 & 120000 & 0.52 & 0.71 & 0.51 & 0.68 \\
\hline $\begin{array}{l}\text { Taiga Plains (4) } \\
\text { Western Boreal }\end{array}$ & 48578650 & 508000 & 574000 & 1.05 & 1.18 & 0.96 & 1.07 \\
\hline Shield (61) & 64206406 & 824000 & 947000 & 1.28 & 1.47 & 1.15 & 1.30 \\
\hline
\end{tabular}

*As Flannigan et al. (2005) reported the total annual area burned in thousands of hectares, we had to first estimate the total area with fuel within each ecozone in order to estimate the proportion of annual area burned (\%) which comply with our model. Area of fuel was estimated using EOSD imagery (Beaubien et al. 1999).

**AAB: Annual area burned

$\S$ The Canadian model used was the First Generation Coupled GCM (CGCM1) for the time period 2080-2100 which roughly corresponds to an equivalent 3 $\times \mathrm{CO} 2$ scenario when including both greenhouse gas and sulphate aerosol forcing. The Hadley model, HadCM3GGa1, contained only greenhouse gas forcing and used $2080-2099$ as its equivalent $3 \times$ CO2 scenario. 


\section{References}

714 Beaubien J, Cihlar J, Simard G, Latifovic R (1999) Land cover from multiple thematic 715 mapper scenes using a new enhancement-classification methodology. Experiment and Science Overview. J Geophys Res 104: 909-927.

717 Bergeron Y, Cyr D, Drever CR, Flannigan M, Gauthier S, Kneeshaw D, Lauzon E, Leduc A, Le Goff H, Lesieur D, Logan K (2006) Past, current, and future fire frequencies in Quebec's commercial forests: implications for the cumulative effects of harvesting and fire on age-class structure and natural disturbance-based management. Can J For Res 36: 2737-2744.

722 Bergeron Y, Flannigan M, Gauthier S, Leduc A, Lefort P (2004) Past, current and future

723 fire frequency in the Canadian boreal forest: Implications for sustainable forest

724 management. Ambio 33:356-360.

725 Flannigan MD, Logan KA, Amiro BD, Skinner WR, Stocks BJ (2005) Future area

726 burned in Canada. Clim. Change 72: 1-16. doi:10.1007/s10584-005-5935-y. 
Supplementary material S2 - a) Proportion (\%) of the HFR zone that is

729 "harvestable", i.e., where total volume is at least $100 \mathrm{~m}^{3} \cdot \mathrm{ha}^{-1}$ and b) mean stand age

730 according to different anthropogenic forcing scenarios when considering (solid lines)

731 or not (dashed lines) fire - vegetation feedbacks. See figure 2 for color meaning.

a)
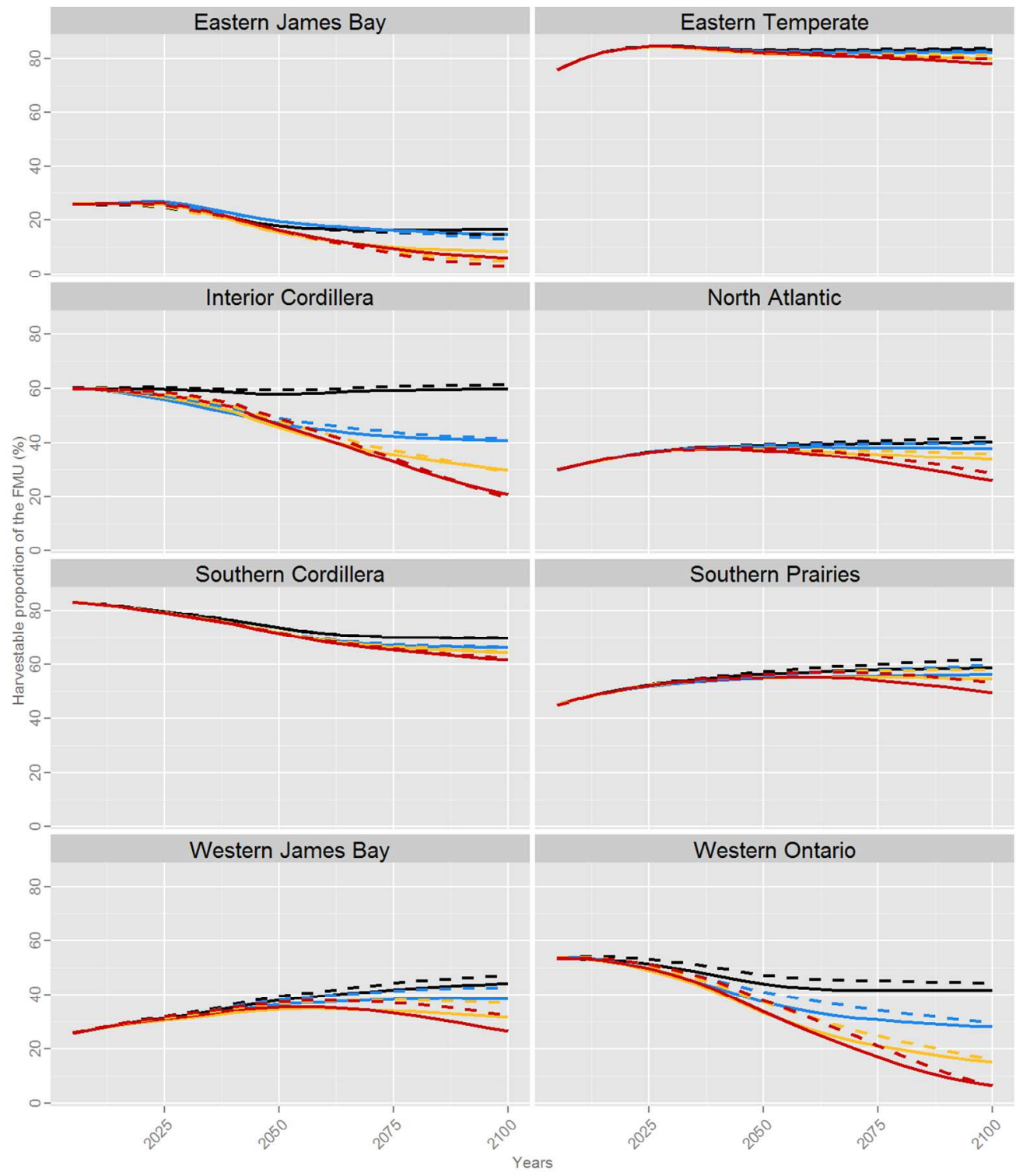

scenario

- baseline

- RCP26

- RCP45

- RCP85 
b)

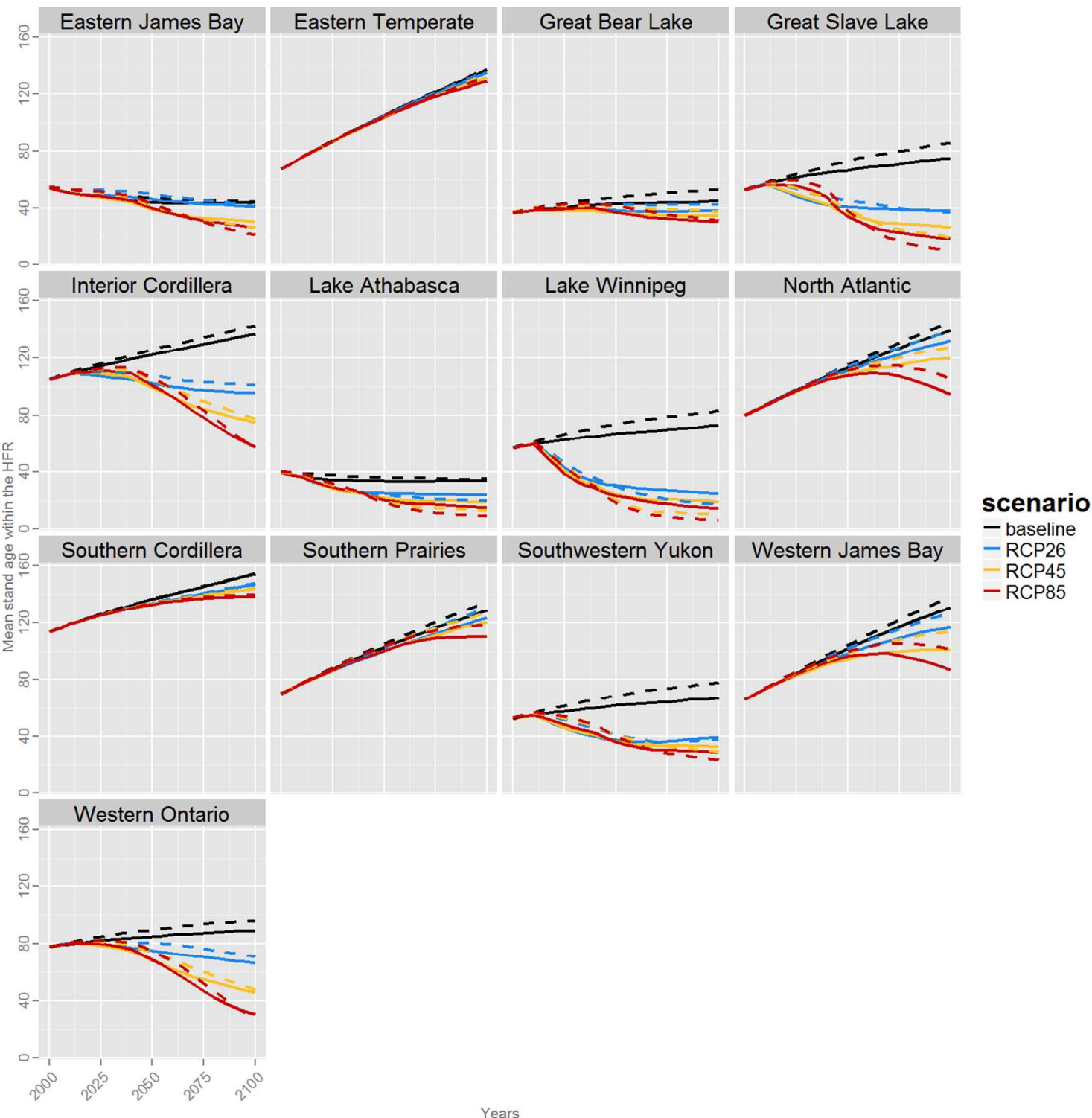


Supplementary Material S3 - Animated figures showing the ratio between year $t$ and year $=2000$ for the fraction of harvestable stands (above $100 \mathrm{~m} 3$.ha-1) or for the total harvested volume in each FMU as simulated under baseline, RCP 2.6, RCP 4.5 and RCP 8.5. Results are shown for simulations where biotic feedbacks were included. 